\title{
Influence of Successive Chemical and Thermochemical Treatments on Surface Features of Ti6A14V Samples Manufactured by SLM
}

\author{
Jesús E. González ${ }^{1}$ **, Gabriela de Armas ${ }^{1}$, Jeidy Negrin ${ }^{1} \mathbb{D}$, Ana M. Beltrán ${ }^{2} \mathbb{D}$, Paloma Trueba ${ }^{2}$, \\ Francisco J. Gotor ${ }^{3}{ }^{(D}$, Eduardo Peón ${ }^{1}$ and Yadir Torres ${ }^{2}(\mathbb{D}$ \\ 1 Departamento de Biomateriales Cerámicos y Metálicos, Centro de Biomateriales, Universidad de La Habana, \\ La Habana 6323, Cuba; gdearmasortiz@gmail.com (G.d.A.); jeidy930924@gmail.com (J.N.); \\ epeon@biomat.uh.cu (E.P.) \\ 2 Departamento de Ingeniería y Ciencia de los Materiales y el Transporte, Escuela Politécnica Superior, \\ Universidad de Sevilla, 41011 Sevilla, Spain; abeltran3@us.es (A.M.B.); ptrueba@us.es (P.T.); \\ ytorres@us.es (Y.T.) \\ 3 Instituto de Ciencia de Materiales de Sevilla (CSIC-US), 41011 Sevilla, Spain; francisco.gotor@icmse.csic.es \\ * Correspondence: jgonzalezr1961@gmail.com; Tel.: +53-58454530
}

Citation: González, J.E.; Armas, G.d.; Negrin, J.; Beltrán, A.M.; Trueba, P.; Gotor, F.J.; Peón, E.; Torres, Y. Influence of Successive Chemical and Thermochemical Treatments on Surface Features of Ti6Al4V Samples Manufactured by SLM. Metals 2021 11, 313. https://doi.org/10.3390/ met11020313

Academic Editor: Eric Hug

Received: 24 January 2021

Accepted: 8 February 2021

Published: 11 February 2021

Publisher's Note: MDPI stays neutral with regard to jurisdictional claims in published maps and institutional affiliations.

Copyright: (c) 2021 by the authors. Licensee MDPI, Basel, Switzerland. This article is an open access article distributed under the terms and conditions of the Creative Commons Attribution (CC BY) license (https:// creativecommons.org/licenses/by/ $4.0 /)$

\begin{abstract}
Ti6Al4V samples, obtained by selective laser melting (SLM), were subjected to successive treatments: acid etching, chemical oxidation in hydrogen peroxide solution and thermochemical processing. The effect of temperature and time of acid etching on the surface roughness, morphology, topography and chemical and phase composition after the thermochemical treatment was studied. The surfaces were characterized by scanning electron microscopy, energy dispersive $\mathrm{X}$-ray spectroscopy, X-ray diffraction and contact profilometry. The temperature used in the acid etching had a greater influence on the surface features of the samples than the time. Acid etching provided the original SLM surface with a new topography prior to oxidation and thermochemical treatments. A nanostructure was observed on the surfaces after the full process, both on their protrusions and pores previously formed during the acid etching. After the thermochemical treatment, the samples etched at $40{ }^{\circ} \mathrm{C}$ showed macrostructures with additional submicro and nanoscale topographies. When a temperature of $80^{\circ} \mathrm{C}$ was used, the presence of micropores and a thicker anatase layer, detectable by X-ray diffraction, were also observed. These surfaces are expected to generate greater levels of bioactivity and high biomechanics fixation of implants as well as better resistance to fatigue.
\end{abstract}

Keywords: selective laser melting; Ti6Al4V; acid etching; chemical oxidation; thermochemical treatment; surface features

\section{Introduction}

Titanium and its alloys are widely used in the manufacturing of biomedical devices, especially dental and orthopedic implants, which operate under high biomechanical loads [1-3]. Titanium has a moderate capacity to osseointegrate, excellent mechanical characteristics and great resistance to corrosion in biological fluids [4-6]. However, there are significant differences between the chemical and phase composition presented by these materials and those of bone tissues. Therefore, their insertion into the human skeleton may result in the absence of strong bonds between the bone and implant. Commonly, the Ti6Al4V alloy is one of the most widely used in the medical world, since it significantly increases the strength, ductility and fatigue resistance of the implants, which could prevent their fracture $[2,7,8]$.

In the last two decades, a kind of technological revolution involving advanced biomaterials, structure designs and new manufacturing methods for implantable medical devices has notably improved the clinical success of surgical operations for the treatment of hard tissue affections [9]. Additive manufacturing (AM) is a new concept involving 
the industrial production of objects through which the material is deposited layer by layer $[10,11]$. Using this technique, which is also known as three-dimensional (3D) printing, custom geometric shapes can be produced depending on the needs of each patient [11]. This process is suitable for producing low-volume parts with great shape complexity. AM has beneficial features, such as high precision, freedom of design, minimization of waste, production of components directly from digital files, as well as lightweight parts with complex scales. It also reduces the cost of product development and cycle time [12].

One of the advantages of AM, is that it provides extensive customization for medical applications based on individual patient data and requirements, and enables the design and manufacture of patient-specific implants [12-14], which are modeled in 3D sections. For this reason, in recent years there has been notable progress in the implementation of AM in the field of biofabrication. Selective laser melting (SLM) and electron beam melting (EBM) have been selected in most research studies as suitable methods for fabricating scaffolds for bone tissue engineering (BTE), due to their good controllability and high level of precision [11,15]. The SLM technique is used in biomedicine to print complex geometries and lightweight structures and, since printed components can have thin walls, deep cavities, and hidden channels, it has a high potential for being used for the manufacturing of porous objects, such as metal scaffolds. For instance, by SLM, it is possible to manufacture implants with porous 3D structures known as lattice structures [12].

In the last 30 years, a great deal of effort has been devoted to obtaining a biological answer related to the topology and chemistry of the surface of implants [16]. Increasing cellular activity on the implant surface is of great importance to accelerate the growth of bone tissue. The relationship between surface topography and cell viability has drawn increasing attention to a wide variety of surface modification approaches [16,17]. Nanoscale profiles may play an important role in the adsorption of extracellular matrix (ECM) proteins and in cell adhesion properties [2,18]. Micro/nanoscale surface topography has been confirmed to modulate cellular functions and have positive effects on the differentiation, orientation, adhesion of osteoblasts and implant osseointegration [19,20]. In different studies, human osteoblasts were found to prefer surfaces with nanometric topologies [6].

Some works have addressed the manufacturing and characterization of specimens of the commercially pure (c.p.) titanium and Ti6Al4V alloys, made by SLM [21-23]. SLM titanium and SLM Ti6A14V samples have shown good biocompatibility both in vitro and in vivo [24]. However, their topography and surface chemistry are not the most appropriate for achieving rapid osseointegration $[17,25]$. In this context, to improve the biocompatibility and osseointegration of SLM Ti6Al4V implants, several surface modification treatments have been proposed in the literature [26-30], obtaining roughness surface at submicro and nanoscale level. However, no studies have been found in which these surface treatments were able to obtain and control roughness features ranging from the macroscale to the nanoscale. Therefore, the main goal of this investigation is to evaluate the role of different consecutive surface treatments: acid etching (influence of temperature and time), chemical oxidation and thermochemical treatment on the surface features of SLM Ti6Al4V samples.

\section{Materials and Methods}

\subsection{Fabrication of Ti6Al4V Samples}

The samples were designed with Inventor Professional three dimensional computeraided design (3D CAD) Inventor software (Autodesk Inc, Mill Valle, CA, USA). Plates with a size of around $10 \mathrm{~mm} \times 5 \mathrm{~mm} \times 5 \mathrm{~mm}$ were made on the SLM250 selective laser melting machine (SLM 250 ${ }^{\mathrm{HL}}$, SLM solutions $\mathrm{GmbH}$, Lübeck, Germany). The samples were printed in the z-direction (parallel to the longitudinal direction of the plates) in an argon atmosphere. A Ti6Al4V alloy powder (grade 5 supplied by SLM Solutions GmbH) with spherical morphology and an average diameter of $31 \pm 12 \mu \mathrm{m}$, with dimensions between 10 and $65 \mu \mathrm{m}$, was used. Details of the raw powder have already been reported in a previous work [31]. An ytterbium fiber laser, with a power of $200 \mathrm{~W}$, line scanning 
strategy using antiparallel stripes, hatch distance of $120 \mu \mathrm{m}$ and thickness of the powder layer of $50 \mu \mathrm{m}$, were used.

\subsection{Surface Modification Treatments}

The surface modification process of the Ti6Al4V samples used during the development of this research can be summarized as described in Figure 1. First, the samples were subjected to an acid etching (AE) treatment. A mixture of $\mathrm{HCl} / \mathrm{H}_{2} \mathrm{SO}_{4}$ at $67 \%$ with a $v / v$ 1:1 ratio was prepared according to the procedure described by Zhang et al. [32] and the samples were immersed in this mixture using one of the four treatment regimens shown in Table 1 . Then, they were washed using distilled water in an ultrasonic bath for $10 \mathrm{~min}$ and dried in an oven at $90^{\circ} \mathrm{C}$ for $1 \mathrm{~h}$. Later, the chemical oxidation (C) treatment of samples in a mixture of $\mathrm{H}_{2} \mathrm{O}_{2}$ and $\mathrm{HCl}$ was carried out according to the procedure reported by Wang et al. $[33,34]$. Test tubes, with $5 \mathrm{~mL}$ of a mixture of $\mathrm{H}_{2} \mathrm{O}_{2}$ with a concentration of $8.8 \mathrm{~mol} / \mathrm{L}$ and $0.1 \mathrm{~mol} / \mathrm{L}$ of $\mathrm{HCl}$ with a $v / v 1: 1$, were placed in a thermostatic water bath at $80{ }^{\circ} \mathrm{C}$ and the samples were submerged in the oxidizing mixture for $30 \mathrm{~min}$. The specimens were then washed again with distilled water and dried in an oven at $90{ }^{\circ} \mathrm{C}$ for $1 \mathrm{~h}$. Finally, a thermochemical (T) treatment was carried out in a furnace at $400{ }^{\circ} \mathrm{C}$ for $1 \mathrm{~h}$, using a heating regime of $10{ }^{\circ} \mathrm{C} / \mathrm{min}$. The successive chemical oxidation and thermochemical treatments were applied to the samples obtained with the four AE regimens shown in Figure 1. Table 1 summarizes the label of the samples and the successive superficial treatment of each of them $(\mathrm{AE}+\mathrm{C}+\mathrm{T}, \mathrm{AECT})$. For instance, AECT-1 means this substrate was subjected to a sequential acid etching (AE) a $40{ }^{\circ} \mathrm{C}$ during $8 \mathrm{~min}$, followed by a chemical oxidation (C) and, then, thermochemical treatment $(\mathrm{T})$.

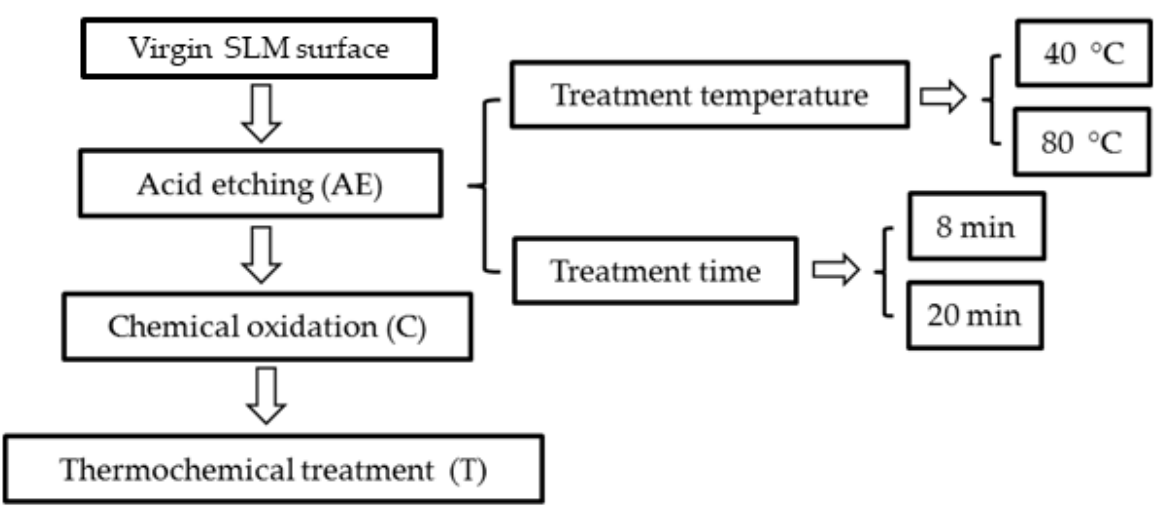

Figure 1. Schematic representation of the surface treatments used. SLM: selective laser melting.

Table 1. Acid etching treatments. All samples were superficially modified with successive chemical oxidation treatment (at $80^{\circ} \mathrm{C}$ for $30 \mathrm{~min}$ ) and thermochemical treatment (at $400{ }^{\circ} \mathrm{C}$ for $1 \mathrm{~h}$ ).

\begin{tabular}{ccc}
\hline \multirow{2}{*}{ Sample Denomination } & \multicolumn{3}{c}{ Acid Etching (AE) } \\
\cline { 2 - 3 } & $\mathbf{T}\left({ }^{\circ} \mathbf{C}\right)$ & $\mathbf{t}(\mathbf{m i n})$ \\
\hline AECT-1 & \multirow{2}{*}{40} & 8 \\
AECT-2 & & 20 \\
\hline AECT-3 & \multirow{2}{*}{80} & 8 \\
AECT-4 & & 20 \\
\hline
\end{tabular}

\subsection{Surface Characterization}

Surface morphology of different samples was studied by field emission scanning electron microscopy (FE-SEM) (S-4800, Hitachi, Japan). The semi-quantitative elemental composition was measured using energy dispersive $X$-ray spectroscopy coupled with scanning electron microscopy (EDX-SEM) (Quantax EDS, Bruker Corporation, Mannheim, Germany). Surface topographical features (i.e., protuberances, size of the pores) were 
measured using the software ImageJ version 1.44. The X-ray diffraction (XRD) patterns of the surfaces were acquired with a PANalytical $X^{\prime}$ Pert Pro diffractometer, using $\mathrm{Cu} \mathrm{K} \alpha$ radiation $\left(\lambda=0.1542 \mathrm{~nm}\right.$ ) with $40 \mathrm{kV}$ and $40 \mathrm{~mA}$, a step size of $0.05^{\circ}$, a counting time of $80 \mathrm{~s} /$ step and a diffraction angle 2 Theta between $20^{\circ}$ and $80^{\circ}$. The surface roughness $\left(R_{a}\right)$ of the samples before and after the thermochemical treatment was measured using a contact profilometer (Surftest SJ-210, Mitutoyo, Japan) at $0.5 \mathrm{~mm} / \mathrm{s}$, using the standard UNE-ENISO 4287:1999 [35]. Two replicas of each surface were used, and data were acquired five times on each sample.

\subsection{Statistical Analysis}

All experimental measurements are presented as the mean value \pm standard deviation (SD). At least one replica of each experimental run was used, with more than 50 measurements of the micropore, sub micropore and protrusion sizes. In addition, more than 5 measurements of the $R_{a}$ of each sample were performed. The data were analyzed using StatGraphics Centurion XV software (Statpoint Technologies, Warrenton, VA, USA). Multiple-sample comparison tests (multiple range tests, Tukey HSD) were used to determine significant differences among groups. A value of $p<0.05$ was taken as a statistically significant difference.

\section{Results}

\subsection{Acid Etching of SLM Surface}

Different AE regimens (Table 1) were performed to determine the influence of the temperature and time on the topographical surface features of Ti6Al4V samples after the full surface modification process (Figure 1). As an example, the SEM images of the Ti6Al4V sample before and after the acid etching at $80{ }^{\circ} \mathrm{C}$ for $20 \mathrm{~min}$ are displayed in Figure 2. The as-prepared SLM samples showed surface morphological features according to those reported in previous studies (Figure 2a) [25,36]. Residual partially melted powder particles (protrusions) were found on the surface of the native SLM samples that showed a rough wavy surface without nano-topographic characteristics. On the surfaces subjected to the AE process, a significant variation of the topography and morphology (Figure 2a,b) was observed in comparison with the SLM surfaces. In samples etched at $80{ }^{\circ} \mathrm{C}$, micropores were revealed on the surfaces, which were not observed when etched at $40{ }^{\circ} \mathrm{C}$. Higher micropores content was noticed on the surfaces of samples etched at $80^{\circ} \mathrm{C}$ for 20 min with an average size of $6.1 \pm 3.2 \mu \mathrm{m}$. Furthermore, some grooves with a width of around $9 \mu \mathrm{m}$ and parallel orientation between them were observed. On the other hand, the mean size of the protrusions on the AE surface decreased from $31 \pm 12 \mu \mathrm{m}$ to $28 \pm 10 \mu \mathrm{m}$ according to the dimensional losses observed in Figure 2.

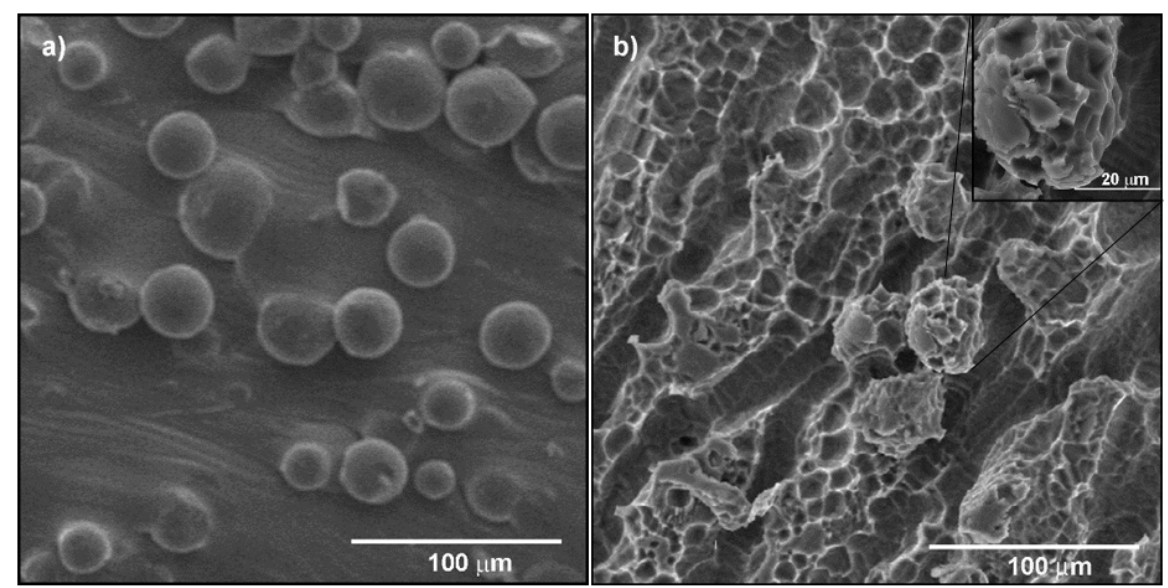

Figure 2. SEM micrographs of the surface of the Ti6Al4V alloy samples obtained by SLM before and after the acid etching (AE). (a) SLM surface, (b) AE surface (etched at $80^{\circ} \mathrm{C}$ for $20 \mathrm{~min}$ ). Inset: higher magnification image. 
The superficial elemental composition of the SLM and AE surfaces was determined by EDX-SEM (Figure 3). In general, the spectra acquired after etching are similar to those observed on the surface of the SLM samples without treatment. Peaks associated with $\mathrm{Ti}, \mathrm{Al}$ and V were identified. Only a slightly higher Al content was observed on the AE surfaces. Moreover, a new peak was detected on these surfaces, which was assigned to S. The presence of this element must be related to the existence of $\mathrm{H}_{2} \mathrm{SO}_{4}$ in the acid mixture.

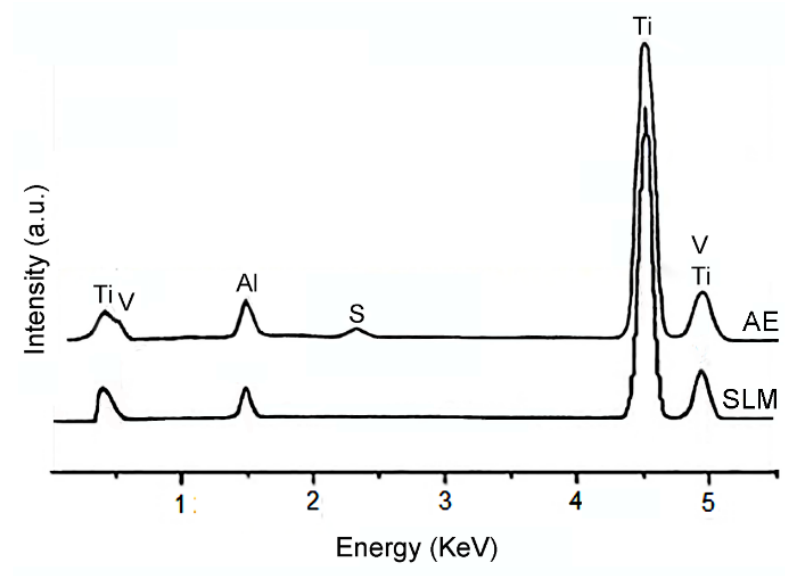

Figure 3. EDX-SEM spectra of the surface of SLM and AE samples.

\subsection{Successive Chemical Oxidation and Thermochemical Treatments of the Acid Etched Ti6Al4V Surfaces}

Figure 4 shows the SEM images of the surface of the Ti6Al4V samples subjected to successive acid etching, chemical oxidation (in $\mathrm{H}_{2} \mathrm{O}_{2} / \mathrm{HCl}$ mixture) and thermochemical $\left(400{ }^{\circ} \mathrm{C}\right.$ for $1 \mathrm{~h}$ ) treatments (AECT surfaces). AECT surfaces differed by the AE regimen used (Table 1) and two surface topographies were observed. The AECT-1 and AECT-2 samples presented a similar topography to the SLM samples, while the surface of the AECT-3 and AECT-4 samples additionally showed micropores. In Figure 4, it is possible to appreciate the size and the size distribution of the spheroidal protrusions present on the surfaces of these samples.

The AECT surfaces showed protrusions with diameters between 6 and $60 \mu \mathrm{m}$ and an average diameter of about $30 \mu \mathrm{m}$, as could be observed in the histograms (insets Figure 4). In general, no statistically significant differences were found when comparing the diameter of the protrusions of the AECT surfaces with the AE surfaces. However, a slight increase in this parameter was observed in the AECT surfaces. Neither statistically significant differences were found between the diameter of the protrusions on the four AECT evaluated surfaces. On the other hand, on AECT-3 and AECT-4 surfaces, the presence of micropores can be observed with an average diameter of $4.8 \pm 2.8 \mu \mathrm{m}$ and $5.2 \pm 2.0 \mu \mathrm{m}$, respectively. This parameter decreased in about $1 \mu \mathrm{m}$ compared to that presented by the AE surfaces and, furthermore, statistically significant differences were found when the micropore diameter on AECT-3 and AECT-4 surfaces was compared with AE surfaces. The micropores appeared not only on the protrusions, but also on the rest of the surface and had a concave configuration with the tendency to adopt a spheroidal shape. Note that the pores cover a greater surface area in the sample subjected to the treatment at $80^{\circ} \mathrm{C}-20 \mathrm{~min}$ (AECT-4), while this was not observed in the samples treated at $40{ }^{\circ} \mathrm{C}$ (AECT- 1 and AECT2). Porous surfaces on implants provide high frictional resistance between the host bones and high primary stability. After implantation, the bone tissues can grow into the pores, and biological fixation is achieved [26]. 

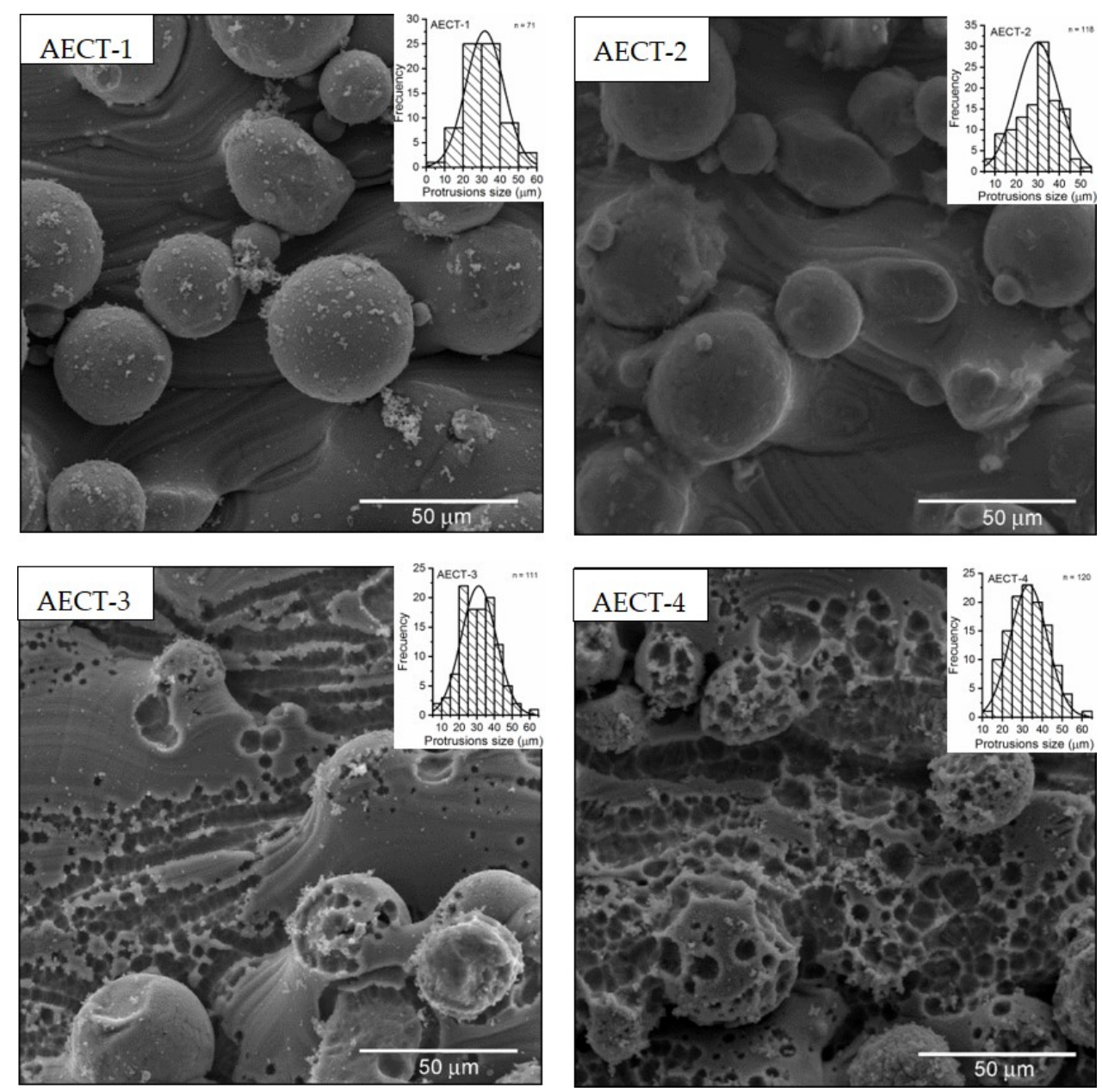

Figure 4. SEM micrographs AECT surfaces at low magnification and protrusions size distribution on AECT surfaces.

The SEM images at higher magnification of the AECT samples show the presence of structures at the submicrometric and nanometric scale (Figure 5), as a result of the chemical reaction between the titanium and the $\mathrm{H}_{2} \mathrm{O}_{2} / \mathrm{HCl}$ mixture [34]. Specifically, on all surfaces, a three-dimensional interconnected network with an open porous structure, formed by nanosheets that surround nano-submicropores was observed. The aforementioned network structure could be seen both on the surface of the protrusions and inside the pores previously formed in the AE process. The nano-submicropores (dark areas, while lighter areas were the sheets; see Figure 5) exhibited an irregular shape with an average size of around $130 \mathrm{~nm}$. No statistically significant differences were found when comparing the average size of these pores for all studied surfaces. Some microcracks were also observed, which probably originated during the heating and cooling steps of the thermochemical treatment of the samples. In addition, structures with spheroidal shape and size of about one micrometer were detected.

In general, two multiscale topographies were observed after the successive chemical and thermochemical oxidation treatments. These topographies are related to the time and temperature used during acid etching. In the samples with acid etching at $40{ }^{\circ} \mathrm{C}$ (AECT-1 and AECT-2), macro, submicro and nanoscale structures were observed, while in the samples treated at $80{ }^{\circ} \mathrm{C}$ (AECT-3 and AECT-4), micropores were additionally seen. In recent years, the combination of micro- and nano-features has attracted the attention of researchers $[14,18,19,37]$. $\mathrm{Xu}$ et al. have reported that the presence of micronano topography in SLM titanium allowed significantly higher osteoblast proliferation, total protein contents, bone-implant contact (BIC) and bone-bonding force than in as- 
built SLM [25]. In this sense, the nanotopographical features increase the surface area of biomaterials and may contribute to increased protein adsorption [18], the adhesion of osteoblasts and the osseointegration of the implant surface [17]. Therefore, it is expected that the surfaces could improve the cell response and the osseointegration of the implants.

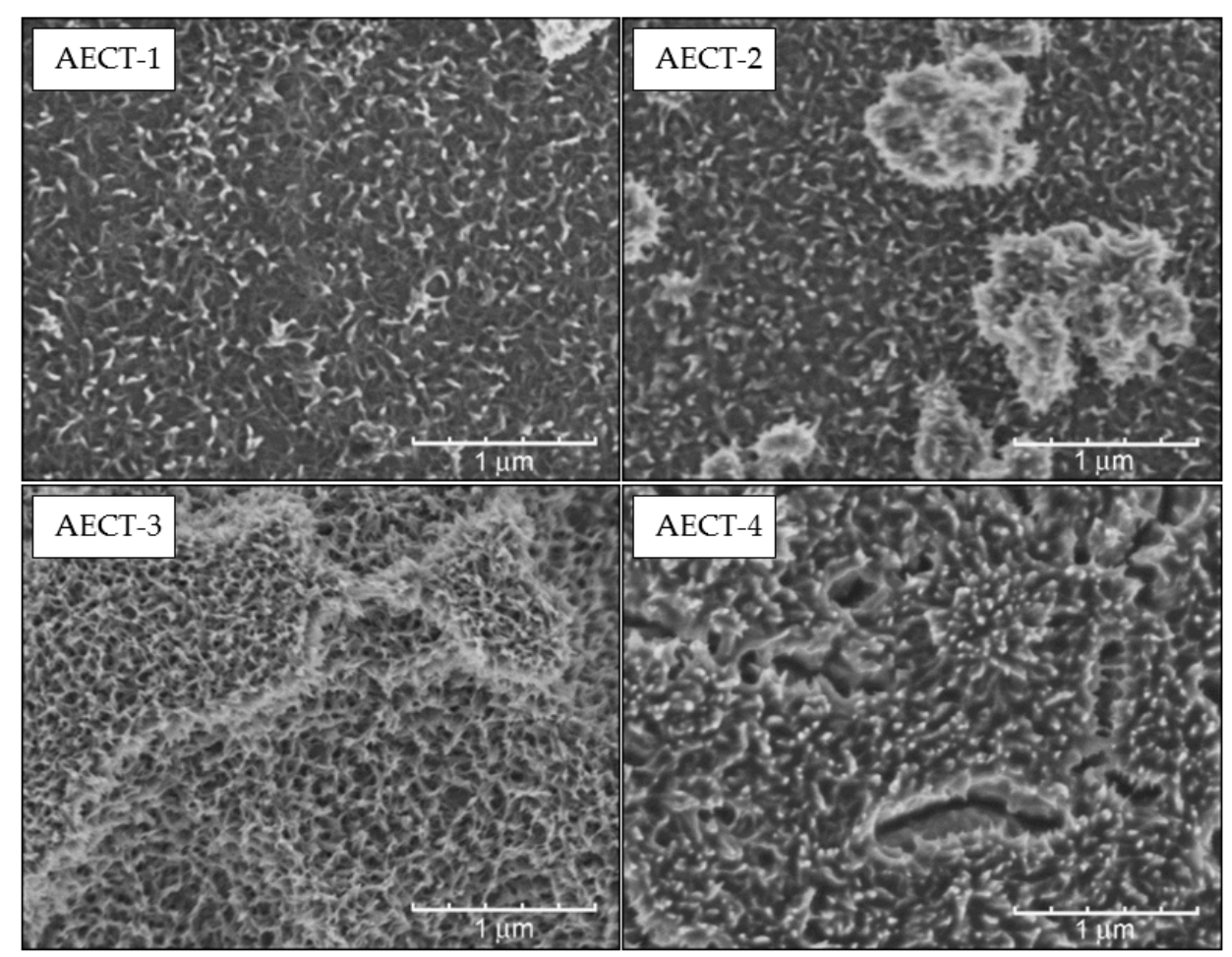

Figure 5. SEM micrographs of the surface of AECT samples at high magnification.

EDX-SEM spectra of the surfaces subjected to the chemical oxidation and thermochemical treatments are shown in Figure 6. Peaks of Ti, Al and V corresponding to the starting composition and additional $\mathrm{O}$ were observed. The presence of high oxygen content (around $40 \%$ ) must be related to the formation of an oxide scale layer. The spectra did not show the peak corresponding to $\mathrm{S}$ detected on the $\mathrm{AE}$ surfaces that was probably eliminated during the $\mathrm{H}_{2} \mathrm{O}_{2} / \mathrm{HCl}$ chemical oxidation. In general, the $\mathrm{Al}, \mathrm{V}$ and Ti contents on these surfaces remained lower than on the SLM and AE surfaces, but the Ti/Al/V ratio was similar to that of the AE surfaces.

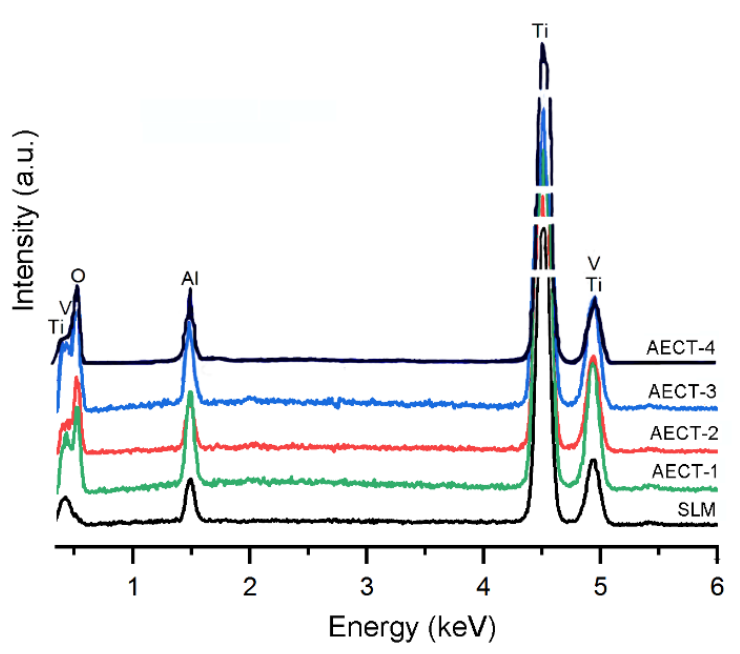

Figure 6. EDX-SEM spectra of SLM and AECT surfaces. 
Figure 7 shows the XRD patterns of the surface of the SLM samples before and after the successive surface modification treatments evaluated in this work. The presence of the $\alpha$ phase, with hcp crystal structure, was clearly observed. The existence of a small amount of the cubic $\beta$ phase cannot be excluded. The low intensity XRD peaks also observed in Figure 7 were assigned to anatase $\mathrm{TiO}_{2}(2$ Theta $=25.28$ and 75.03). The low intensity of these peaks was related to the small thickness of the oxide layer (according with the results of Wang et al., the anatase layer thickness was estimated to be about $30 \mathrm{~nm}$ [33]). The titania gel obtained during the treatment of Ti in $\mathrm{H}_{2} \mathrm{O}_{2}$ solution was transformed into an anatase crystal structure after heating between 400 and $500{ }^{\circ} \mathrm{C}$ [34]. Su et al. reported that protein adsorption and subsequent cellular responses could be also affected by the surface functional groups [38]. Specifically, anatase has excellent bioactivity and significant differences have been found in the percentage of BIC between the anatase layer and control implants during the early stages of bone regeneration [39]. On the other hand, the formation of a titanium oxide layer increases the corrosion resistance of the titanium alloy and prevents the release of ions into the body fluid [40]. In this sense, accumulation of aluminum has been observed around Ti6Al4V implants, which could be harmful; therefore, a proper passivating layer would reduce the risk of aluminum release [41].

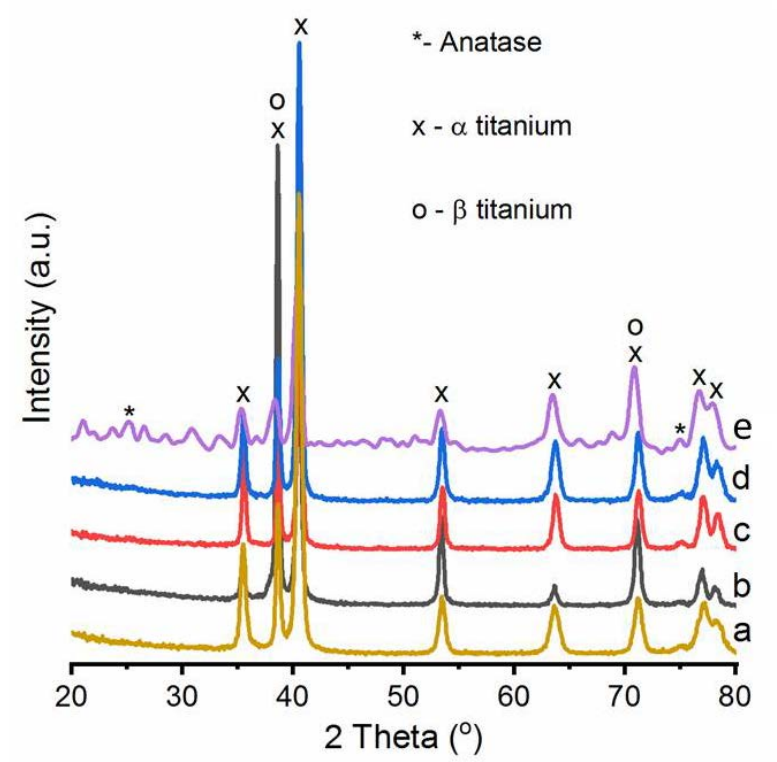

Figure 7. XRD patterns of SLM and AECT surfaces. (a) SLM, (b) AECT-1, (c) AECT-2, (d) AECT-3 and (e) AECT-4.

Figure 8 shows $R_{a}$ values of the AE and AECT surfaces. In general, rough surfaces were observed in all the samples $\left(R_{a}\right.$ average between 6.8 and $\left.7.5 \mu \mathrm{m}\right)$. These $R_{a}$ values were slightly lower than those obtained for the SLM surfaces $\left(R_{a}=9.35 \pm 0.47 \mu \mathrm{m}\right)$ and were like those reported by Benedetti et al. [42]. On the other hand, different studies have reported $R_{a}$ values in the range of 6 and $40 \mu \mathrm{m}$ on as built SLM Ti6Al4V parts [42-45]. The surface roughness of samples manufactured by SLM depends on several factors: material, processing parameters, laser inclination angle to the build platform, build direction, particle size distribution and parts spacing [46-50]. Both the transition boundaries between layers and partially melted powder particles contribute to the overall roughness of the top surfaces. In the top surface, the roughness differs strongly from the roughness of side surfaces [43]. The influence of the partially melted particles on the surface roughness increases as the inclination angle increases, and it is the primary cause of surface roughness when the inclination angle is close to $90^{\circ}$ [50]. In this sense, it has been reported that specimens built in the $45^{\circ}$ direction show higher levels of roughness than the vertically built specimens. 


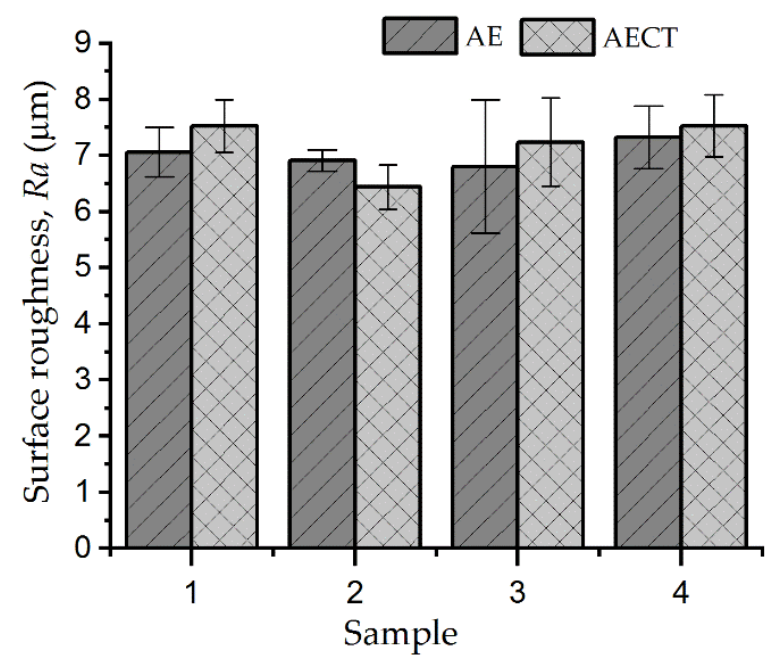

Figure 8. Surface roughness in AE and AECT samples. (1) AECT-1, (2) AECT-2, (3) AECT-3, (4) AECT-4.

In general, larger $R_{a}$ values were observed in AECT surfaces compared to the $\mathrm{AE}$ surfaces. Nevertheless, no statistically significant differences were found between the Ra values of the AE and AECT surfaces $(p>0.005)$. On the other hand, the AECT surfaces only showed slight differences between their $R_{a}$ values. Several studies have demonstrated the influence of the surface roughness of titanium implants on their osseointegration rate and biomechanical fixation [3]. The rough surface could increase the anchorage possibility of the bone cells and, according to Bose et al., the intrinsic roughness of the AM surfaces can increase tissue integration, implant fixation and, also, the mechanical adherence of coatings [16]. Benedetti et al. investigated the effect of shot peening and electropolishing in SLM Ti6Al4V samples on cell growth at different times [51]. The surface roughness decreased because of these treatments, but they found no influence of these surfaces on cell growth at $90 \mathrm{~h}$ of incubation. Additionally, Tsukanaka et al. stated that a rough surface was beneficial for early mechanical stability, but for osteoblast differentiation and bone formation, the surface must undergo a bioactive treatment [26].

Endosseous implants under load bearing must maintain high mechanical properties, biocompatibility and osseointegration over a time scale exceeding at least two decades [51]. The multiscale topography, chemical and phase composition obtained in the AECT-3 and AECT-4 surfaces must generate adequate biocompatibility and fast osseointegration of the implants. Although the mechanical properties of SLM Ti6Al4V samples are superior, compared to conventionally manufactured parts, this is not the case in the high-cycle fatigue regime [52,53]. The fatigue performance of as built SLM Ti6Al4V components is over $75 \%$ lower than wrought materials, due to their surface finish, porosity and residual stresses [54]. In this sense, it was reported that as built Ti6Al4V parts manufactured by SLM after a stress relief treatment have a fatigue resistance of $240 \mathrm{MPa}$ at $5 \times 10^{6}$ cycles [51]. The fatigue crack initiation life depends on different factors, such as residual stresses, surface roughness, internal defects, microstructure and microstructural inhomogeneities. For built SLM specimens, surface roughness has been found to be the most influential factor in reducing fatigue life $[55,56]$. The mean fatigue life of SLM Ti6Al4V parts decreases with increasing surface roughness due to the stress concentration at the surface [52,57]. Different post-melting treatments, such as heat treatment, machining, acid etching, polishing, shot peening, hot isostatic pressing (HIP) and electropolishing, were used to increase the resistance of SLM Ti6Al4V parts to fatigue $[44,51,52,58]$. The best results were obtained when stress-relief treatments were used, followed by at least one of the following processes: machining, shot peening or HIP $[44,51,59]$. The machining processes reduce surface roughness and subsurface defects, but its use in complex geometries is difficult. On the other hand, shot peening and HIP reduce surface defects and create a surface compressive residual stress layer [51]. 
Porous coatings have also been associated with decreases in the fatigue life of medical devices [60]. Smith considered that the decrease in endurance limited, to sintered porous coatings, was related to pores and cracks in the layer [61]. Apachitei et al. found a significant increase in fatigue resistance by decreasing the thickness of porous coatings by plasma electrolytic oxidation (PEO) on titanium alloys [60]. They also observed that, in the coatings in which anatase prevails over rutile, the fatigue strength values were increased. According to Khan et al., the anatase coatings induced compressive stresses [62], which must improve the fatigue performance of the treated implant.

As previously stated, it is expected that the surfaces acid etched at $80^{\circ} \mathrm{C}($ AECT-3 and AECT-4), which present macro-micro-submicro and nanoscale structures and, in addition, an anatase layer, would generate greater levels of bioactivity and high biomechanic fixation of implants to the bone. However, these surfaces had greater porosity, which could also affect their resistance to fatigue. Thus, future research should determine the influence of the two topographies obtained on the biological behavior of the endosseus implants, using in vitro and in vivo tests. In addition, the influence of the surface features obtained in the AECT samples on the fatigue resistance of SLM biomedical devices should be evaluated.

\section{Conclusions}

In this work, the effect of successive processes of acid etching, chemical oxidation and thermochemical treatment of Ti6Al4V samples (AECT surfaces) manufactured by selective laser melting was evaluated. It was found that AECT surfaces showed significant differences in their topography and elemental composition in comparison with the $\mathrm{AE}$ surfaces. The temperature used in the AE process had a greater influence on the surface features of the samples. Two topographies were obtained on the AECT surfaces as a function of the temperature used during acid etching. After the thermochemical treatment at $400{ }^{\circ} \mathrm{C}$ for $1 \mathrm{~h}$, the samples subjected to acid etching at $40{ }^{\circ} \mathrm{C}$ (AECT- 1 and AECT-2 samples) showed macro structures combined with submicro and nano scale topographies, characterized by the absence of micropores. The samples with acid etching at a temperature of $80^{\circ} \mathrm{C}$ (AECT-3 and AECT-4 samples) also showed a multiscale topography in which additionally micropores were observed. A network shape structure was observed on all surfaces, both on their protrusions and inside their pores previously formed in the acid etching. In addition, thermochemical treatment caused an increase in oxygen content on the Ti6Al4V surface, the formation of an anatase thin layer and a micropore size decrease.

Author Contributions: Conceptualization, project administration, supervision, methodology, J.E.G., E.P., F.J.G. and Y.T., investigation, formal analysis, validation, G.d.A., J.N., A.M.B. and P.T., discussion and writing - original draft preparation, all the authors. All authors have read and agreed to the published version of the manuscript.

Funding: This work was supported by the Ministry of Science and Innovation of Spain under the grant PID2019-109371GB-I00, by the Junta de Andalucía-FEDER (Spain) through the Project Ref. US-1259771.

Institutional Review Board Statement: Not applicable.

Informed Consent Statement: Not applicable.

Data Availability Statement: Not applicable.

Acknowledgments: The authors are sincerely grateful to the to the "Luces" project of IMRE, University of Havana for its collaboration in conducting tests.

Conflicts of Interest: The authors declare no conflict of interest.

\section{References}

1. Gagg, G.; Ghassemieh, E.; Wiria, F.E. Effects of sintering temperature on morphology and mechanical characteristics of 3D printed porous titanium used as dental implant. Mater. Sci. Eng. C 2013, 33, 3858-3864. [CrossRef]

2. Tsai, P.-I.; Lam, T.-N.; Wu, M.-H.; Tseng, K.-Y.; Chang, Y.-W.; Sun, J.-S.; Li, Y.-Y.; Lee, M.-H.; Chen, S.-Y.; Chang, C.-K. Multi-scale mapping for collagen-regulated mineralization in bone remodeling of additive manufacturing porous implants. Mater. Chem. Phys. 2019, 230, 83-92. [CrossRef] 
3. Shibata, Y.; Tanimoto, Y. A review of improved fixation methods for dental implants. Part I: Surface optimization for rapid osseointegration. J. Prosthodont. Res. 2015, 59, 20-33. [CrossRef] [PubMed]

4. Bai, L.; Gong, C.; Chen, X.; Sun, Y.; Zhang, J.; Cai, L.; Zhu, S.; Xie, S.Q. Additive manufacturing of customized metallic orthopedic implants: Materials, structures, and surface modifications. Metals 2019, 9, 1004. [CrossRef]

5. Yadroitsava, I.; du Plessis, A.; Yadroitsev, I. Bone regeneration on implants of titanium alloys produced by laser powder bed fusion: A review. In Titanium for Consumer Applications, 1st ed.; Elsevier: Amsterdam, The Netherlands, 2019; pp. 197-233.

6. Miranda, G.; Sousa, F.; Costa, M.; Bartolomeu, F.; Silva, F.; Carvalho, O. Surface design using laser technology for Ti6Al4Vhydroxyapatite implants. Opt. Laser Technol. 2019, 109, 488-495. [CrossRef]

7. Chang, J.; Tsai, P.-I.; Kuo, M.; Sun, J.-S.; Chen, S.-Y.; Shen, H.-H. Augmentation of DMLS Biomimetic Dental Implants with Weight-Bearing Strut to Balance of Biologic and Mechanical Demands: From Bench to Animal. Materials 2019, 12, 164. [CrossRef]

8. Sui, Q.; Li, P.; Wang, K.; Yin, X.; Liu, L.; Zhang, Y.; Zhang, Q.; Wang, S.; Wang, L. Effect of Build Orientation on the Corrosion Behavior and Mechanical Properties of Selective Laser Melted Ti-6Al-4V. Metals 2019, 9, 976. [CrossRef]

9. Yuan, L.; Ding, S.; Wen, C. Additive manufacturing technology for porous metal implant applications and triple minimal surface structures: A review. Bioact. Mater. 2019, 4, 56-70. [CrossRef]

10. Bartolomeu, F.; Dourado, N.; Pereira, F.; Alves, N.; Miranda, G.; Silva, F. Additive manufactured porous biomaterials targeting orthopedic implants: A suitable combination of mechanical, physical and topological properties. Mater. Sci. Eng. C 2020, 107, 110342. [CrossRef]

11. Zhang, X.-Y.; Fang, G.; Zhou, J. Additively manufactured scaffolds for bone tissue engineering and the prediction of their mechanical behavior: A review. Materials 2017, 10, 50. [CrossRef]

12. Dhiman, S.; Sidhu, S.S.; Bains, P.S.; Bahraminasab, M. Mechanobiological assessment of Ti-6Al-4V fabricated via selective laser melting technique: A review. Rapid Prototyp. J. 2019, 25, 1266-1284. [CrossRef]

13. Javaid, M.; Haleem, A. Additive manufacturing applications in medical cases: A literature based review. Alex. J. Med. 2018, 54, 411-422. [CrossRef]

14. Bouet, G.; Cabanettes, F.; Bidron, G.; Guignandon, A.; Peyroche, S.; Bertrand, P.; Vico, L.; Dumas, V. Laser-Based Hybrid Manufacturing of Endosseous Implants: Optimized Titanium Surfaces for Enhancing Osteogenic Differentiation of Human Mesenchymal Stem Cells. ACS Biomater. Sci. Eng. 2019, 5, 4376-4385. [CrossRef]

15. Oliveira, T.T.; Reis, A.C. Fabrication of dental implants by the additive manufacturing method: A systematic review. J. Prosthet. Dent. 2019, 122, 270-274. [CrossRef]

16. Bose, S.; Robertson, S.F.; Bandyopadhyay, A. Surface modification of biomaterials and biomedical devices using additive manufacturing. Acta Biomater. 2018, 66, 6-22. [CrossRef] [PubMed]

17. Xiong, Y.; Gao, R.; Zhang, H.; Li, X. Design and fabrication of a novel porous titanium dental implant with micro/nano surface. Int. J. Appl. Electromagn. Mech. 2019, 59, 1097-1102. [CrossRef]

18. Wang, G.; Moya, S.; Lu, Z.; Gregurec, D.; Zreiqat, H. Enhancing orthopedic implant bioactivity: Refining the nanotopography. Nanomedicine 2015, 10, 1327-1341. [CrossRef] [PubMed]

19. Ferraris, S.; Bobbiob, A.; Miola, M.; Sprianoa, S. Micro- and nano-textured, hydrophilic and bioactive titanium dental implants. Surf. Coat. Technol. 2015, 276, 374-383. [CrossRef]

20. Cohen, D.J.; Cheng, A.; Sahingur, K.; Clohessy, R.M.; Hopkins, L.B.; Boyan, B.D.; Schwartz, Z. Performance of laser sintered Ti-6Al-4V implants with bone-inspired porosity and micro/nanoscale surface roughness in the rabbit femur. Biomed. Mater. 2017, 12, 025021. [CrossRef] [PubMed]

21. Bartolomeu, F.; Costa, M.; Gomes, J.; Alves, N.; Abreu, C.; Silva, F.; Miranda, G. Implant surface design for improved implant stability-A study on Ti6Al4V dense and cellular structures produced by Selective Laser Melting. Tribol. Int. 2019, 129, 272-282 [CrossRef]

22. Wysocki, B.; Idaszek, J.; Zdunek, J.; Rożniatowski, K.; Pisarek, M.; Yamamoto, A.; Święszkowski, W. The influence of selective laser melting (SLM) process parameters on in-vitro cell response. Int. J. Mol. Sci. 2018, 19, 1619. [CrossRef] [PubMed]

23. Wally, Z.J.; Haque, A.M.; Feteira, A.; Claeyssens, F.; Goodall, R.; Reilly, G.C. Selective laser melting processed Ti6Al4V lattices with graded porosities for dental applications. J. Mech. Behav. Biomed. Mater. 2019, 90, 20-29. [CrossRef] [PubMed]

24. Wang, H.; Zhao, B.; Liu, C.; Wang, C.; Tan, X.; Hu, M. A comparison of biocompatibility of a titanium alloy fabricated by electron beam melting and selective laser melting. PLOS ONE 2016, 11, e0158513. [CrossRef] [PubMed]

25. Xu, J.-Y.; Chen, X.-S.; Zhang, C.-Y.; Liu, Y.; Wang, J.; Deng, F.-L. Improved bioactivity of selective laser melting titanium: Surface modification with micro-/nano-textured hierarchical topography and bone regeneration performance evaluation. Mater. Sci. Eng. C 2016, 68, 229-240. [CrossRef] [PubMed]

26. Tsukanaka, M.; Fujibayashi, S.; Takemoto, M.; Matsushita, T.; Kokubo, T.; Nakamura, T.; Sasaki, K.; Matsuda, S. Bioactive treatment promotes osteoblast differentiation on titanium materials fabricated by selective laser melting technology. Dent. Mater. J. 2016, 35, 118-125. [CrossRef] [PubMed]

27. Chen, Z.; Yan, X.; Chang, Y.; Xie, S.; Ma, W.; Zhao, G.; Liao, H.; Fang, H.; Liu, M.; Cai, D. Effect of polarization voltage on the surface componentization and biocompatibility of micro-arc oxidation modified selective laser melted Ti6Al4V. Mater. Res. Express 2019, 6, 086425. [CrossRef]

28. Zhao, D.-P.; Tang, J.-C.; Nie, H.-M.; Zhang, Y.; Chen, Y.-K.; Zhang, X.; Li, H.-X.; Yan, M. Macro-micron-nano-featured surface topography of Ti-6Al-4V alloy for biomedical applications. Rare Met. 2018, 37, 1055-1063. [CrossRef] 
29. Luo, Y.; Jiang, Y.; Zhu, J.; Tu, J.; Jiao, S. Surface treatment functionalization of sodium hydroxide onto 3D printed porous Ti6Al4V for improved biological activities and osteogenic potencies. J. Mater. Res. Technol. 2020, 9, 13661-13670. [CrossRef]

30. Torres, Y.; Sarria, P.; Gotor, F.J.; Gutiérrez, E.; Peon, E.; Beltrán, A.M.; González, J.E. Surface modification of Ti-6Al-4V alloys manufactured by selective laser melting: Microstructural and tribo-mechanical characterization. Surf. Coat. Technol. 2018, 348, 31-40. [CrossRef]

31. Sarria, P.; Torres, Y.; Gotor, F.J.; Gutiérrez, E.; Rodríguez, M.; González, R.; Hernández, L.; Peón, E.; Guerra, H.; González, J.E. Processing and characterization of Ti-6Al-4V samples manufactured by selective laser melting. Key Eng. Mater. 2016, 704, 260-268. [CrossRef]

32. Zhang, E.; Wang, Y.; Gao, F.; Wei, S.; Zheng, Y. Enhanced bioactivity of sandblasted and acid-etched titanium surfaces. Adv. Mater. Res. 2009, 79-82, 393-396. [CrossRef]

33. Wang, X.X.; Hayakawa, S.; Tsuru, K.; Osaka, A. A comparative study of in vitro apatite deposition on heat-, $\mathrm{H}_{2} \mathrm{O}_{2-}$, and $\mathrm{NaOH}$-treated titanium surfaces. J. Biomed. Mater. Res. 2001, 54, 172-178. [CrossRef]

34. Wang, X.-X.; Hayakawa, S.; Tsuru, K.; Osaka, A. Bioactive titania gel layers formed by chemical treatment of Ti substrate with a $\mathrm{H} 2 \mathrm{O} 2 / \mathrm{HCl}$ solution. Biomaterials 2002, 23, 1353-1357. [CrossRef]

35. ISO. ISO 4287; ISO: Geneva, Switzerland.

36. Wu, F.; Xu, R.; Yu, X.; Yang, J.; Liu, Y.; Ouyang, J.; Zhang, C.; Deng, F. Enhanced Biocompatibility and Antibacterial Activity of Selective Laser Melting Titanium with Zinc-Doped Micro-Nano Topography. J. Nanomater. 2019, 2019, 1-14. [CrossRef]

37. Xu, R.; Hu, X.; Yu, X.; Wan, S.; Wu, F.; Ouyang, J.; Deng, F. Micro-/nano-topography of selective laser melting titanium enhances adhesion and proliferation and regulates adhesion-related gene expressions of human gingival fibroblasts and human gingival epithelial cells. Int. J. Nanomed. 2018, 13, 5045. [CrossRef]

38. Su, Y.; Luo, C.; Zhang, Z.; Hermawan, H.; Zhu, D.; Huang, J.; Liang, Y.; Li, G.; Ren, L. Bioinspired surface functionalization of metallic biomaterials. J. Mech. Behav. Biomed. Mater. 2018, 77, 90-105. [CrossRef] [PubMed]

39. He, F.M.; Yang, G.L.; Li, Y.N.; Wang, X.X.; Zhao, S.F. Early bone response to sandblasted, dual acid-etched and $\mathrm{H}_{2} \mathrm{O}_{2} / \mathrm{HCl}$ treated titanium implants: An experimental study in. Int. J. Oral Maxillofac. Surg. 2009, 38, 677-681. [CrossRef]

40. Cao, H.; Liu, X. Activating titanium oxide coatings for orthopedic implants. Surf. Coat. Technol. 2013, 233, 57-64. [CrossRef]

41. Zaffe, D.; Bertoldi, C.; Consolo, U. Accumulation of aluminium in lamellar bone after implantation of titanium plates, Ti-6Al-4V screws, hydroxyapatite granules. Biomaterials 2004, 25, 3837-3844. [CrossRef] [PubMed]

42. Benedetti, M.; Fontanari, V.; Bandini, M.; Zanini, F.; Carmignato, S. Low-and high-cycle fatigue resistance of Ti-6Al-4V ELI additively manufactured via selective laser melting: Mean stress and defect sensitivity. Int. J. Fatigue 2018, 107, 96-109. [CrossRef]

43. Bagehorn, S.; Wehr, J.; Maier, H. Application of mechanical surface finishing processes for roughness reduction and fatigue improvement of additively manufactured Ti-6Al-4V parts. Int. J. Fatigue 2017, 102, 135-142. [CrossRef]

44. Cao, F.; Zhang, T.; Ryder, M.A.; Lados, D.A. A review of the fatigue properties of additively manufactured Ti-6Al-4V. JOM 2018, 70, 349-357. [CrossRef]

45. Vayssette, B.; Saintier, N.; Brugger, C.; El May, M. Surface roughness effect of SLM and EBM Ti-6Al-4V on multiaxial high cycle fatigue. Theor. Appl. Fract. Mech. 2020, 108, 102581. [CrossRef]

46. Bourell, D.; Stucker, B.; Spierings, A.; Herres, N.; Levy, G. Influence of the particle size distribution on surface quality and mechanical properties in AM steel parts. Rapid Prototyp. J. 2011, 17, 195-202.

47. Günther, J.; Leuders, S.; Koppa, P.; Tröster, T.; Henkel, S.; Biermann, H.; Niendorf, T. On the effect of internal channels and surface roughness on the high-cycle fatigue performance of Ti-6Al-4V processed by SLM. Mater. Des. 2018, 143, 1-11. [CrossRef]

48. Vandenbroucke, B.; Kruth, J.P. Selective laser melting of biocompatible metals for rapid manufacturing of medical parts. Rapid Prototyp. J. 2007, 13, 196-203. [CrossRef]

49. Krol, M.; Tański, T. Surface quality research for selective laser melting of Ti-6Al-4V alloy. Arch. Metall. Mater. 2016, 61, 1291-1296. [CrossRef]

50. Strano, G.; Hao, L.; Everson, R.M.; Evans, K.E. Surface roughness analysis, modelling and prediction in selective laser melting. J. Mater. Process. Technol. 2013, 213, 589-597. [CrossRef]

51. Benedetti, M.; Torresani, E.; Leoni, M.; Fontanari, V.; Bandini, M.; Pederzolli, C.; Potrich, C. The effect of post-sintering treatments on the fatigue and biological behavior of Ti-6Al-4V ELI parts made by selective laser melting. J. Mech. Behav. Biomed. Mater. 2017, 71, 295-306. [CrossRef]

52. Fotovvati, B.; Namdari, N.; Dehghanghadikolaei, A. Fatigue performance of selective laser melted Ti6Al4V components: State of the art. Mater. Res. Express 2018, 6, 012002. [CrossRef]

53. Leuders, S.; Meiners, S.; Wu, L.; Taube, A.; Tröster, T.; Niendorf, T. Structural components manufactured by selective laser melting and investment casting-impact of the process route on the damage mechanism under cyclic loading. J. Mater. Process. Technol. 2017, 248, 130-142. [CrossRef]

54. Edwards, P.; Ramulu, M. Fatigue performance evaluation of selective laser melted Ti-6Al-4V. Mater. Sci. Eng. A 2014, 598, 327-337. [CrossRef]

55. Kahlin, M.; Ansell, H.; Moverare, J. Fatigue behaviour of notched additive manufactured Ti6Al4V with as-built surfaces. Int. J. Fatigue 2017, 101, 51-60. [CrossRef]

56. Zhang, J.; Fatemi, A. Surface roughness effect on multiaxial fatigue behavior of additive manufactured metals and its modeling. Theor. Appl. Fract. Mech. 2019, 103, 102260. [CrossRef] 
57. Chan, K.S.; Koike, M.; Mason, R.L.; Okabe, T. Fatigue life of titanium alloys fabricated by additive layer manufacturing techniques for dental implants. Metall. Mater. Trans. A 2013, 44, 1010-1022. [CrossRef]

58. Vayssette, B.; Saintier, N.; Brugger, C.; El May, M.; Pessard, E. Numerical modelling of surface roughness effect on the fatigue behavior of Ti-6Al-4V obtained by additive manufacturing. Int. J. Fatigue 2019, 123, 180-195. [CrossRef]

59. Witkin, D.B.; Patel, D.N.; Helvajian, H.; Steffeney, L.; Diaz, A. Surface treatment of powder-bed fusion additive manufactured metals for improved fatigue life. J. Mater. Eng. Perform. 2019, 28, 681-692. [CrossRef]

60. Apachitei, I.; Lonyuk, B.; Fratila-Apachitei, L.; Zhou, J.; Duszczyk, J. Fatigue response of porous coated titanium biomedical alloys. Scr. Mater. 2009, 61, 113-116. [CrossRef]

61. Smith, T. The effect of plasma-sprayed coatings on the fatigue of titanium alloy implants. JOM 1994, 46, 54-56. [CrossRef]

62. Khan, R.H.; Yerokhin, A.; Matthews, A. Structural characteristics and residual stresses in oxide films produced on Ti by pulsed unipolar plasma electrolytic oxidation. Philos. Mag. 2008, 88, 795-807. [CrossRef] 